\title{
REVITALIZATION OF REGIONAL-OWNED ENTERPRISE (BUMD) GOVERNANCE THROUGH THE PARTICIPATION IN OIL AND GAS MANAGEMENT BY USING GROSS SPLIT MECHANISM
}

\author{
Yudho Taruno Muryanto'; Tuhanan²; Anjar Sri Ciptorukmi ${ }^{3}$ \\ 1,2,3 Faculty of Law, Universitas Sebelas Maret \\ Email: yudho_fhuns@yahoo.com
}

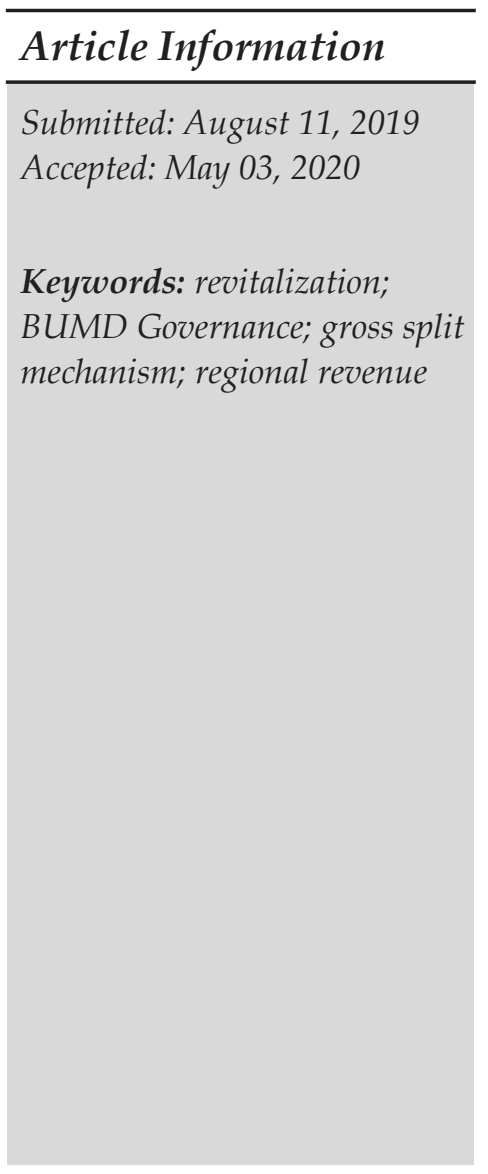

\begin{abstract}
The implementation of the gross split scheme in the upstream oil and gas business by revenue sharing contract is a new phase concerning the existence, especially for regional governments related to the insertion of regional assets. The participation of BUMD in the oil and gas management where the BUMD is located is prominent, in the context of increasing revenue and boosting the regional economy. The involvement of BUMD in oil and gas management is mainly related to the gross split mechanism. There are several problems, among others, related to the problematic management of BUMD whose business activities support the upstream oil and gas business to increase local revenue and how to implement the revitalization of BUMD governance that supports the upstream oil and gas business. This article is the result of empirical legal research by using a conceptual approach. Research techniques and data collection using primary and secondary material by analyzing the data through text interpretation (hermeneutics) and the logic of deduction. Based on the research on the revitalization of BUMD governance in the upstream oil and gas business that uses a gross split mechanism, there are several problems in its management, including overlapping sectoral arrangements regarding BUMD between one regulation with other regulations, management issues, human resources issue, supervision and guidance of BUMD, and restructuring of BUMD.
\end{abstract}

\section{Introduction}

The sovereignty over the natural resource in Indonesia is under the mandate of the Indonesian Constitution of 1945, especially in Article 33 paragraph (2) and paragraph (3):

Paragraph (2): All the production branches which are important for the State and which take control of the public livelihood are controlled by the State.

Paragraph (3): The earth, water, and natural resources contained therein are controlled by the State and used for the maximum of people welfare

The control and management of natural resources by the State are mandated in the provisions of the Indonesian constitution, where natural resources are under the State's authority and are used for the people's welfare. The meaning of mastering can 
be translated as the right of possession to the State. The right of the state to control is a concept in the organization of state control that contains the authority, regulates, and supervises the management or control of minerals, in this case, the management of oil and gas (Abror Saleng, 2004: 24). Not everything can be done by the State regarding the control and management of natural resources including oil and gas. In principle, the scope of control is exercised by the State includes managing and delegating its management of natural resources including oil and gas to other parties, but the State remains sovereignty over mining materials (Adrian Sutedi, 2011: 24).

Most of our natural resources in the upstream oil and gas are managed by foreign contractors. Regarding the management of upstream oil and gas business in Law Number 22 of 2001 concerning Oil and Gas is still using a production sharing contracts system, where this model is underlying on a sophisticated technology factor and the power of capital. Considering that the upstream business activities in oil and gas require high funding and technology so the concept of profit sharing and cooperation becomes prominent in the management of the upstream oil and gas business. The role of BUMD becomes significant when BUMD can support activities in areas where locations where natural resources (such as oil and gas) are located (read: Oil and Gas Block). The gross split mechanism adopted by the Government of Indonesia is a new model as regulated through Ministerial Regulation of Energy and Mineral Resources Number 52 of 2017 On Amendments to Ministerial Regulation of Energy and Mineral Resources Number 8 of 2017 On of Production Sharing Contract by Gross Split Mechanism. In its implementation, the production sharing contract through a gross split mechanism is set at the beginning so that it has a fairness value both for the Government and the contractor because the contractor split will be adjusted to the oil and gas field to be managed later. The existence of this new scheme, the government no longer needs to think about reimbursing of upstream oil and gas operating costs (cost recovery) because this production sharing contract by gross split mechanism will regulate the profit-sharing mechanism obtained from the exploitation and exploration of upstream oil and gas between implementing agencies with permanent business entities.

In connection with the revitalization of BUMD governance to increase regional revenue through upstream oil and gas business management activities, there is use the concept of a controlling company or form a holding company, the concept of a gross split appears expected to be able to boost the performance of BUMD which so far have not been able to significantly contributes to regional revenue. Regional-Owned Enterprises $(B U M D)$ is a form of business that is owned by the regional government, the essence of BUMD is a reflection of the potential development that exists in the region. Besides, $B U M D$ also has an objective to increase regional revenue. But in reality, the existing $B U M D$ s have not been able to make a significant contribution to regional revenue so that what is the main goal of establishing a $B U M D$ as one source of local government revenue has not been achieved (P2 LIPI, 2010).

Along with the development of $B U M D$, a classic problem befalls $B U M D$ where some of the issues that arise are an umbrella rule of BUMD existence and some issues are related to aspects of BUMD management itself. The dualism of the BUMD functions mentioned above makes it difficult for BUMD to face an agile business competition and 
the dependence on the Regional Budget in terms of capital insertion (Jawa Pos, accessed on Thursday 8 March 2012). One of the potentials that are mobilized in accelerating economic development is to give a maximum role to the regional economic institutions called BUMD. BUMD functions as an agent of development and as a public servant in terms of providing the needs of the community that are not provided by other economic actors, as well as its function as a source of Regional Original Revenue, so as a whole the presence of BUMD is expected to be able to provide good "multiplier effects", in the form of improved quality regional economic development (Jawa Pos, accessed on Thursday 8 March 2012).

Fundamentally, the natural resources management that carried out by local governments can be through business sector mechanisms that are operated by BUMD. Accordance with Article 331 paragraph (4) The Law Number 9 of 2015 On Second Amendment to The Law Number 23 of 2014 concerning Regional Government said that the main goal of establishing BUMD, among others (Article 331 paragraph (4) Law Number 23 of 2014 On Local Government) (1) Providing general benefits for the regional economic development; (2) Organizing the public benefits in the form of providing quality goods and/or services for the fulfillment of people's lives according to the conditions, characteristics, and regional potency based on good corporate governance; and (3) Obtaining a profit and/or economic margin. The concept of BUMD's governance can be carried out by adopting stewardship theory and agency theory in which the two theories also underlie the emergence of the principles of good corporate governance. The stewardship theory is built on philosophical assumptions about human nature that human is inherently trustworthy, able to act responsibly, have integrity, and are honest with others. In other words, stewardship theory views management as trustworthy to act in the best way for the public and stakeholder interests (Thomas S. Kaihatu. 2006). Natural resource management that operated by BUMD can be classified into two categories namely renewable natural resources management such as water resources management, plantation, agriculture, husbandry and non-renewable natural resource management such as mining including minerals, coal, oil and gas that requires a comprehensive management model to realize the fundamental goals and regional potency management intent which is carried out by BUMDs can be realized.

In the context of governance, good governance in economics and business and good corporate governance, especially in the regulation and management of BUMDs, makes it very important to build market confidence and encourage long-term investment, not only for the BUMD itself but also for the private sector doing business in the regions. In other words, the application of good governance and good corporate governance (GCG) has a multiplier effect not only in the public sector but also in the private sector (Made Gde Subha Karma Resen, 2015: 10).

The issue of GCG in developed countries as a benchmark for economic performance is the main determinant of public welfare. This concept is growing in developed countries where most investors invest their money or capital in developing countries (Alessio M. Pacces, 2012: 12). This means that the company's success or failure depends on the implementation of GCG (Alessio M. Pacces, 2012: 12). The opinion above also confirmed by the Organization for Economic Co-operation and Development (OECD) and the World 
Bank which states that the principle of good corporate governance is the key to against poverty and economic retardation. In other words, the local government as the controlholder over the BUMD's management, especially those related to natural resources, must certainly consider aspects of good governance without forgetting the aspects of a business management entity following the principles of good corporate governance.

In general, BUMD as a business entity is required to be able to carry out social functions (public) and business functions (private). The social function is carried out by BUMD because BUMD is a company whose component or all of its assets comes from the regional government capital. The regional government is representative of the people or the general public in the participation of BUMD capital through the Regional Budget. Business function (private) BUMD companies that generally have a basic philosophy as a business entity that aims to find profit. The nature of dualism BUMD is, on the one hand, a commercial corporation and on the other hand a social service corporation, so it is necessary to review the form of the BUMD following its line of business (M. Natzir Said, 1985: 293).

\section{Research Methods}

This article is based on secondary data research i.e. data consisting of legal texts, literature, and pre-existing research documents (Soekanto \& Mamudji, 2003:1314). Besides, this article uses a legal approach in which legislation or regulations are interpreted under the context of purpose and legal norms (Barak, 2005; Ibrahim, 2005:61). Therefore, this approach suggests a conceptual investigation of the legislation from which the objective element (procedures) and subjective (legal intent) can be identified (Barak, 2005:88).

\section{Research Result and Discussion}

\section{A. Gross Split Mechanism in Oil and Gas Management}

Concerning the natural resources management in oil and gas, according to Arcandra, as the Vice Minister of the Ministry of Energy and Mineral Resources, said that Indonesia currently has reserves of around 3.3 billion barrels of oil and gas. Assuming constant production of 800,000 barrels per day $(b p d)$, without the new reserves invention, in the next 11 to 12 years Indonesia will not be able to deliver oil and gas anymore. "Arcandra said "but this might not be the next 11-12 years, because production will go down. Next year it might go down to 700,000 (bpd) and even still goes down". Technological factors and new reserves invention, said Arcandra, is the key to the sustainability of oil and gas production in Indonesia. Indonesia's oil reserves which reach 3.3 billion barrels are not classified as abundant reserves. When compared with world oil reserves, Indonesia's oil reserves only equivalent to 0.2 percent. Besides, Indonesia's Reserve Replacement Ratio (RRR) is also still considered low (https://www. esdm.go.id/id/media-center/arsip-berita/ini-angka-cadangan-migas-indonesia-dan-carameningkatkannya, accessed on 28 July 2018).

$40 \quad$ Yustisia Volume 9 Number 1 (January-April 2020)

Revitalization of Regional-Owned... 
Based on the description above, relating to the management of Indonesia's natural resources, especially oil and gas, the statement of Vice Minister of the Ministry of Energy and Mineral Resources is mainly related to "technological factors and new reserve invention" is the major problem of the system and mechanism that will be applied in upstream oil and gas management. Most of our natural resources in the upstream oil and gas business are managed by foreign contractors. Related to upstream oil and gas management in Law Number 22 of 2001 On Oil and Gas still using the production sharing contract model, this is one of the factors underlying technological strength and capital. Considering that the upstream business activities in oil and natural gas require a large amount of capital and high technology, the profit-sharing, and cooperation concept becomes a serious problem in the upstream oil and gas management.

The mechanism of upstream oil and gas management is based on the production sharing contract model which is involving between the contractor and the government as the owner of natural resources, ideally occupies an equal or balanced position in legal relations or each other, so that relationship aspects between the parties who are involved in the upstream oil and gas management are based on private relationships. This paper highlights two crucial issues relating to the mechanism of the upstream oil and gas management by using the Gross Split system. The first issue is related to the legal certainty of the Gross Split mechanism in the PSC contract and the second one is the embodiment of the proportionality principle in the PSC contract using the Gross Split system.

Regulations governing production sharing contracts by using the Gross Split mechanism are regulated through Ministerial Regulation of Energy and Mineral Resources Number 52 of 2017 On Amendments to Ministerial Regulation of Energy and Mineral Resources Number 8 of 2017 On Production Sharing Contracts by Gross Split Mechanism jo. Government Regulation Number 35 of 2004 On Upstream Oil and Gas Business Activities jo. The Law Number 22 of 2001 On Oil and Gas, in which the three regulations contain three fundamental concepts, namely (a) natural resources ownership remains in the hands of the government until the delivery point; (b) operational and management controls are in the hand of Special Task Force for upstream oil and gas, and (c) all capital and risks are borne by the contractor. This also applies to the provisions outlined in the production sharing contract that uses the Gross Split system which contains at least 17 basic provisions that have been specified in The Law Number 22 of 2001 On Oil and Gas.

The implementation of production sharing contracts that use the Gross Split system still has several legal issues, first is the legal conflict, especially with the other regulations or organics regulations. Article 56 paragraph (1) and paragraph (2) of Government Regulation Number 35 of 2004 On Upstream Oil and Gas Business Activities states that:

(1) Arrangement of investment and operating costs from production sharing contracts must obtain approval from the Implementing Body. 
(2) The contractor shall recover the costs incurred to carry out exploration and exploitation as referred to in paragraph (1).

The article above explains that in carrying out upstream oil and gas business activities by using a production sharing contract mechanism (either net or gross) as long as it is based on the distribution of production results, the government will reimburse the costs incurred by the contractor concerning exploration and exploitation activities. This means that Government Regulation Number 35 of 2004 On Upstream Oil and Gas Business Activities still uses the cost recovery system.

Thus, the legal certainty and the position of the party's proportionality in the production sharing contract through the Gross Split mechanism is enable to answer the challenges of the investment climate in Indonesia, especially on oil and gas management. Remembering that several considerations are used as the basis for investors and contractors when carrying out investment activities in a country as stated by Konaito et al (Kohnaito et al, 1998: 87-89), where investment decisions in the mining sector are also determined by the potential of the mine reserves itself "(geological potential), political stability, mineral law including mineral ownership, the security of tenure, exploration/mining term, right to transfer ownerships), fiscal regime and another factor (provisions related management control, environmental obligations, an obligation to workers, market the right to use mineral right as collateral, the confidentiality of data, and dispute settlement mechanism)"

\section{B. Management Problems in The Regional-Owned Enterprises (BUMD)}

BUMD is a business owned by the regional government, where the main goal is as one source of regional revenue. But in reality, the existing BUMDs have not been able to make a significant contribution to regional revenue, instead, there are more injections of funds from local governments than the benefits that can be (Tejomurti, K. 2017: 42-52). These conditions become a hindrance to the regional budget. So that the purpose of the establishment of $B U M D$ is that one source of regional government revenue is not achieved. In addition to the problems outlined above, there are several key issues relating to the management of BUMD, including:

a) Issues regarding an umbrella rule for governing of BUMD.

Adjustment and harmonization associated with an umbrella rule governing BUMD are done by synchronizing vertically or horizontally. Vertical synchronization can be done by adjusting the legislation based on the regulatory hierarchy. Horizontal synchronization is done by looking at the functions of each of the laws and regulations that govern or relate to BUMD. Based on the synchronization method, it is necessary to conduct a study related to an umbrella rule that regulates BUMD (; therefore the BUMD management can be carried out following its shape and characteristics. 
b) Governance issues.

In managing BUMD, the main problem faced by BUMD managers is that not all BUMDs implement BUMD systems and management based on the principles of Good Corporate Governance. This constraint is due to the structure and characteristics of BUMD in each different region. The difference in BUMD management systems is due to the different characteristics of BUMD. In principle, BUMD is divided into two forms, namely Regional Public Companies (Perumda) and Regional Companies (Pereroda). The vision and mission of each BUMD varies according to its characteristics

c) Human Resources Problems.

In managing BUMD, the problem that often arises is about the human resources that manage the BUMD itself. The main problem in managing $B U M D$ is the inability of Human Resources to manage and be competent in their fields. The determination of the ranks and personnel who will occupy the BUMD in the form of Regional Public Companies (Perumda) and Regional Companies (Perseroda) has a lot of confusion with the interests of the parties at both the executive and legislative levels. These two elements of interest are prone to deviations; given the concept of BUMD which is a business entity owned by the regional government cannot be separated from the interests between the regional government (executive) and the interests of the legislative parties. Shortly, goodwill is needed from each party.

d) Problems in supervision and guidance

Regarding supervision and fostering, it must be adjusted to the form and characteristics of BUMD. BUMD in the form of Regional Public Company (Perumda) and Regional Company (Perseroda) in terms of supervision requires suitable and appropriate policies. The regional government as the majority shareholder of BUMD, especially in the form of a Regional Company (Perseroda), can pour its policy through the general meeting of shareholders (RUPS). Conditions are different from BUMD in the form of Regional Public Corporation (Perumda), the intervention of local government policy as the majority shareholder can be done immediately without going through the RUPS, and can be done whenever the local government wants to formulate policies in the management of BUMD. In terms of supervision activities, local governments can make some regional regulations to supporting those supervision policies

e) Problems with a restructuring of BUMD

The restructuring of BUMD can be done by carrying out an inventory related to the grouping of the forms, types, and characteristics of BUMD (Gumbira, S. W., \& Wiwoho, J. 2019 :361-378). The large number and characteristics of BUMD in each region have led to the management of BUMD not being focused. To achieve good corporate governance, several adjustments are needed, including the construction of the form and legal status of the BUMD itself, development of human resources, and upgrading of management. 


\section{The Strategy of BUMD Revitalization Through The Holding of A Similar Company which Engaged in Upstream Oil and Gas}

Based on the categories and characteristics of a Regional Company (Perseroda), according to this paper, the management model is more suitable to use the similar concept which is applied to the management in a State-Owned Enterprise (BUMN), namely by forming a supervise company or group company or called a holding company. The management concept of a Regional Company (Perseroda) by using a holding company is an effort to boost the company's performance so that BUMDs, especially those in the form of a 'company', do not have a dependency on local government assistance (Pranoto, P., Kholil, M., \& Tejomurti, K. 2019: 105) but legally and business entities are independent however still become part and controlled by the local government as the owner of the company. In connection with the revitalization of BUMD Governance in the framework of increasing regional original revenue through upstream oil and gas business activities using management strategies in the form of a Regional Company (Perseroda), then the strategy adopted is to use the concept of a controlling company or form a holding company specifically for business sectors that processing oil and gas. The strategy of BUMD revitalization through holding companies actually could boost company performance; therefore BUMD does not depend on the local government's assist. Revitalization of BUMD management through holding companies in the form of a Regional Company (Perseroda) especially those engaged in oil and gas ought to choose with a vertical group model because this model can be applied to BUMDs that have the same type and business characteristics (upstream and downstream).

\section{Conclusion}

The revitalization of BUMD governance in the upstream oil and gas business-facing several key issues such as (1) issues regarding an umbrella rule for governing of BUMD; (2) governance issues; (3) human resources problems; (4) problems in supervision and guidance; and (5) problems with a restructuring of BUMD. In connection with the revitalization of BUMD Governance in the framework of increasing regional original revenue through upstream oil and gas business activities using management strategies in the form of a Regional Company (Perseroda), then the strategy adopted is to use the concept of a controlling company or form a holding company specifically for business sectors that processing oil and gas. The strategy of BUMD revitalization through holding companies actually could boost company performance; therefore BUMD does not depend on local government assistance. Revitalization of BUMD management through holding companies in the form of a Regional Company (Perseroda) especially those engaged in oil and gas ought to choose with a vertical group model because this model can be applied to BUMDs that have the same type and business characteristics (upstream and downstream). 


\section{BIBLIOGRAPHY:}

\section{Books:}

Abror Saleng. (2004). Hukum Pertambangan. Sinar Grafika: Jakarta.

Adrian Sutedi. (2011). Hukum Pertambangan.Sinar Grafika: Jakarta.

\section{Journals:}

Gumbira, S. W., \& Wiwoho, J. (2019). The Implication of the Globalization on the Pancasila-Based Principles of Local Democracy in Indonesia. Padjadjaran Journal of Law, 6(2), 361-378.

Kohnaito et all. (1998). Mineral Project in ascan Countries, Geologi, regulation, Fiscal regime and the Enviromenment, Resource policy, Vol 24 April.

Parulian shihotang. (2003). A longitudinal Analysis of Indonesian Production Sharing Contract (PSC); The Question of Economic Accountability, Journal The Winners, Vol 4 No 2, September.

Pranoto, P., Kholil, M., \& Tejomurti, K. (2019). FINTECH LENDING: CHALLENGE AND OPPORTUNITIES OF THE INDONESIA'S LOAN UNBANKED TO DEVELOP THE INCLUSIVE FINANCIAL INDUSTRY. Hang Tuah Law Journal, 3(2), 105-119.

Sani Saidu. (2014), A Comparative Analysis of Production Sharing Contract of selected Develeping Countries: Nigeria, Indoensia, Malaysia, and Equatorial Guinea, Journal of Finance and Accounting, volume 2 Number 2.

Tejomurti, K. (2017). Pertanggungjawaban Hukum yang Berkeadilan terhadap Aparatur Pemerintah pada Kasus Pengadaang Barang dan Jasa. Dialogia Iuridica: Jurnal Hukum Bisnis dan Investasi, 8(2), 42-52.

Zurairah ariff abd ghadas, types and features of international protelium contrac, South east asia journal of contemporary business, economic and law, vol 4 issue 3 (june) ISSN2289-1560 h 39.

\section{Legal Documents:}

Law Number 22 of 2001 On Oil and Gas

Government Regulation Number 35/2004 concerning Upstream Oil and Gas Business Activities.

Ministerial Regulation of Energy and Mineral Resources Number 52 of 2017 on Amendments to Ministerial Regulation of Energy and Mineral Resources Number 8 of 2017 on Production Sharing Contracts by Gross Split Mechanism.

https://www.esdm.go.id/id/media-center/arsip-berita/ini-angka-cadangan-migasindonesia-dan-cara-meningkatkannya. Diakses pada tanggal 28 Juli 2018 Pk. 09.55 WIB). 